\title{
Housing and resettlement of Jakarta's urban poor: case study of Kampung Pulo's slum revitalisation in Jakarta, Indonesia
}

\author{
Astrid Meilasari-Sugiana*, Deffi Ayu Puspito Sari, \\ Rini Anggraini
}

Universitas Bakrie, Jakarta, Indonesia

This paper analyses the interface between policy and practice in housing Jakarta's urban poor and revitalising the Kampung Pulo neighbourhood along the Ciliwung riverbank. The paper discusses issues faced by policymakers in securing land and housing for Jakarta's poor, in relocating the majority of Kampung Pulo's residents into housing flats in Central Jakarta and in revitalising the remaining slum areas into semi-permanent settlements with basic facilities. The paper combines top-down policy analysis and bottom-up ethno-methodology to illustrate best practices and contribute to the body of knowledge relating to sustainable urban governance.

Key Words: landscape governance, collective action, urban environmental management, revitalisation.

Article Info: Received: September 5, 2018; Revised: November 9, 2018; Accepted: November 10, 2018; Online: November 30, 2018.

\section{Introduction}

As a developing country with a population of 250 million, Indonesia is experiencing urbanisation at an unprecedented rate. Indonesia's population grows at a rate of $1.04 \%$ per annum, with a total projected population of 290 million in 2045. The country's urban areas are experiencing environmental pressures well beyond their current carrying capacity. Roughly $60 \%$ of Indonesia's population lives in cities. The total estimated number living in the country's capital, Jakarta,

\section{* Corresponding author}

Address: Komplek BNR Jl. Bukit 05 No.07RT 05/012 Mulyaharja, Bogor Selatan, West Java, Indonesia

Phone: + 6282112721136 | Email: astrid.sugiana@bakrie.ac.id

(C)2018 Human Geographies; The authors

(c) (7) This work is licensed under a

Creative Commons Attribution 4.0 International License. DOI:10.5719/hgeo.2018.122.4 
reaches $28,019,545$, with a density of 45,000 inhabitants per square kilometre. A lowland coastal city in the northern part of Java, Jakarta faces many environmental issues related to urban sprawl and squatters, seasonal flooding, solid waste disposal, groundwater pollution, and freshwater shortages.

Population density, disparity and the implementation of market mechanisms in land use planning and allocation have contributed to inequality in Jakarta's land use pattern and forced a majority of the city's poor to live as squatters in state-owned, hazardous sites near railroad tracks, around waste disposal sites and along Jakarta's polluted river banks (Ansari and von Einsiedel, 1998). Jakarta's poor lack of integration into the labour market, they have low purchasing power and possess limited access to land and essential urban infrastructure facilities such as water supply and sanitation. A common practice among Jakarta's low-income community includes converting river banks into land for housing and diverting the flow of the river for aqua-culture purposes. These practices lead to sedimentation, shallow river basin, and a change in the course of the river.

Jakarta's main river, the Ciliwung, flows from the Pangrango Mountain in the Bogor highlands, meanders through the city centre and empties into the Java Sea. The Ciliwung traverses the city's most prevalent low-income community in Kampung Pulo District. The need for housing among Jakarta's poor riverbank communities caused the riverbank's conversion into slums and semi-permanent housing sites. The destruction of catchment areas, when coupled with the alteration of Ciliwung's riverbank and illegal solid waste disposal, further intensifies Jakarta's yearly flooding and environmental destruction. Recent floods in Jakarta incurred an economic loss of $\$ 3.3$ billion, with recovery costs surmounting to $\$ 32$ million and actual loss to $\$ 8$ million. Increased settlement of the Ciliwung riverbank began in the early 1970s when the country embarked on its long-term economic development policy. Coupled with rapid industrialisation and manufacturing growth, during the 1980s Jakarta's urban agglomeration grew in size and population, and large plots of land were converted into industrial complexes, housing estates and business districts as Indonesia was engulfed in the market economy process and land commercialisation. Land and housing for Jakarta's poor have become a serious issue and government administrations at the national and municipal level struggle in securing land and housing for the urban poor (Meilasari, 2015).

In order to revitalise the Ciliwung riverbank and restore its ecosystem function, in 2015 Jakarta's Governor Basuki Tjahaya Purnama relocated a majority of the city's poor from the riverbank into housing flats (i.e. rumah susun) located on government land. After relocating residents, Governor Purnama initiated the revitalisation of Ciliwung's remaining slum areas and converted the landscape into semi-permanent settlements for the poor with access to roads, fresh water, drainage, sanitation, and solid-waste disposal sites (Benveniste, 1991). The provincial government's effort was met with hostility and contention from squatters and the governor's adversaries. In Jakarta, land and housing for the poor extends far beyond the limited technical and administrative concerns which occupy housing officials. In the case of Kampung Pulo, it also extends beyond the limits of the provincial government and into the realm of politics and governance with national political parties and the country's ministries vying 
for power and authority to influence and radicalise slum dwellers for the benefit of a handful group of influential individuals. Indonesian politicians are well aware that squatters can play a variety of political roles. Politicians who were Governor Purnama's adversaries and rivals used urban housing and land tenure issues to radicalise and heighten the conservatism of squatters by appealing to their need to secure possession of their property. This led to the major uprising of squatters and, with approval and support from investors, politicians and officials who opposed the governor's political leadership and expediency. The event earned strong national media coverage and the Indonesian president's attention before nearly tumbling Governor Purnama's effort of relocation and revitalisation (URDI, 2005).

Moreover, the government's public administration bureaucracies did not necessarily follow the footsteps of Governor Purnama's new policy to relocate and revitalise and often pursue their own self-interests. Conflicts of interests among government agencies flared, with the Ministry of Environment mostly interested in restoring the riverbank's ecological functions, the Ministry of Social Work interested in devolving land use tenure to the poor and reorganizing the slums, the National Investment Coordinating Board interested in emptying and reserving the land for commercial and real estate investors (Chiddick and Millington, 1984), the Ministry of Public Works interested in building low income flats for commercialization and profit generating purposes, and the Department of Tax and Revenue interested in generating land and housing taxes from residents living in slums and housing flats. In the case of Kampung Pulo's relocation and revitalisation program, the administrative machinery needed to affect an extensive tenure change program requires control over the bureaucracy that in Jakarta's government administration system was largely curtailing, if not missing. The umbrella coordinating agency for policy planning and implementation, namely Jakarta's provincial government, lacked power, autonomy and authority to enforce the national ministries to follow its directions and stipulations in securing land and housing for the poor, in relocating residents into flats and in revitalising slums along the riverbank.

In addition, the technical and administrative capabilities of the current public administration system to secure land tenure and housing for Jakarta's poor were limited. Jakarta's newcomers, many of whom illegally squatting in the government-owned land (Anggraini, 2005) reported to having paid monthly tributes to agencies from the tax department as well as paying bills for illegal access to the state's electricity and drinking water facilities. In time a perception in which the government affirms and protects the squatters' rights along with their illegal settlements e-merged, and squatters saw themselves entitled to refusing eviction and/or to compensations in the event of an eviction. This paved the way for today's intractable conflicts between government agencies and illegal squatters which dominate many of Jakarta's slum revitalisation policies and programs. Many of Kampung Pulo's squatters were engaged in informal and/or semi-legal occupations and preferred the unregistered status of squatter houses to a properly registered occupancy license in newly revitalised slum areas for fear of high taxes and rents. On the other hand, squatting in Jakarta, when encouraged by the prospects of legalised land and housing tenure, continues unabated despite the official policy of evicting new arrivals. 
Without resorting to a comprehensive and integrated plan to house Jakarta's squatters in government-subsidised, low-income flats legally, the implicit sanction given by the local government to newly arrived city dwellers may lead to further illegal incursion and squatting in new, unoccupied territories.

With regard to the occupation and management of Kampung Pulo's revitalised slum areas, changes in land tenure conditions led to many unpredictable consequences. The first important consequence is that once an adequate measure of informal land and housing tenure security existed, the willingness to obtain and pay for the price of official legal titles dropped considerably. Moreover, once improvement works had been carried out and a few residents had obtained land leasing permits from the government as stipulated by the government's new regulations, the interest in obtaining land leasing permits and in paying land taxes decreased whereas those with land leasing permits felt less inclined to continue retaining the permit and to continue paying for the permit. Lastly, a consequence of improved land and housing tenure security was the displacement of the original lower income population by higher income households. The case of Kampung Pulo suggested that proper attention has to be paid to the desired form of land tenure before a commitment to a complicated administrative process starts. For the effective implementation of land and housing tenure, an appropriate tenure arrangement must be found, proper public administrative mechanisms established in advance, procedures simplified and sufficient resources available for swift action. In the absence of political will, citizen participation and bureaucratic preparedness, the good intentions of politicians, governments and legislators may be drowned in endless officialdom and reduced to social and political dissonance.

\section{Kampung Pulo District along Jakarta's Ciliwung river}

Kampung Pulo is a low-income, semi-permanent settlement in East Jakarta located along the Ciliwung River. Kampung Pulo has a total area of +8 ha. The total number of population in 2010 amounts to 10,022 inhabitants, with a density of 1,255 inhabitants per hectare. Kampung Pulo suffers from regular flooding and is built on protected government ground intended for water catchment and drainage. Yearly floods in Kampung Pulo can reach as high as 3 meters. In 2015, Jakarta's provincial government redirected Ciliwung's flow to its normal course through its urban revitalisation program. Kampung Pulo is located strategically, with public transports surrounding the area and local residents enjoy running water and electricity at subsidised costs provided by Jakarta's provincial government. Narrow alleys traverse the settlement area intended for pedestrians and motorcycles.

Population density, conversion of Ciliwung's riverbank and drainage facilities into settlement areas and illegal solid waste disposal into the river render the neighbourhood vulnerable to floods during rainy seasons when the river rises (photo 1). Moreover, many of the remaining open spaces in Kampung Pulo are paved with concrete which exacerbates floods and destructions. The abatement of floods and natural hazards requires relocating Kampung Pulo's residents onto flats and low-income apartments in safer neighbourhoods. In 2015, 


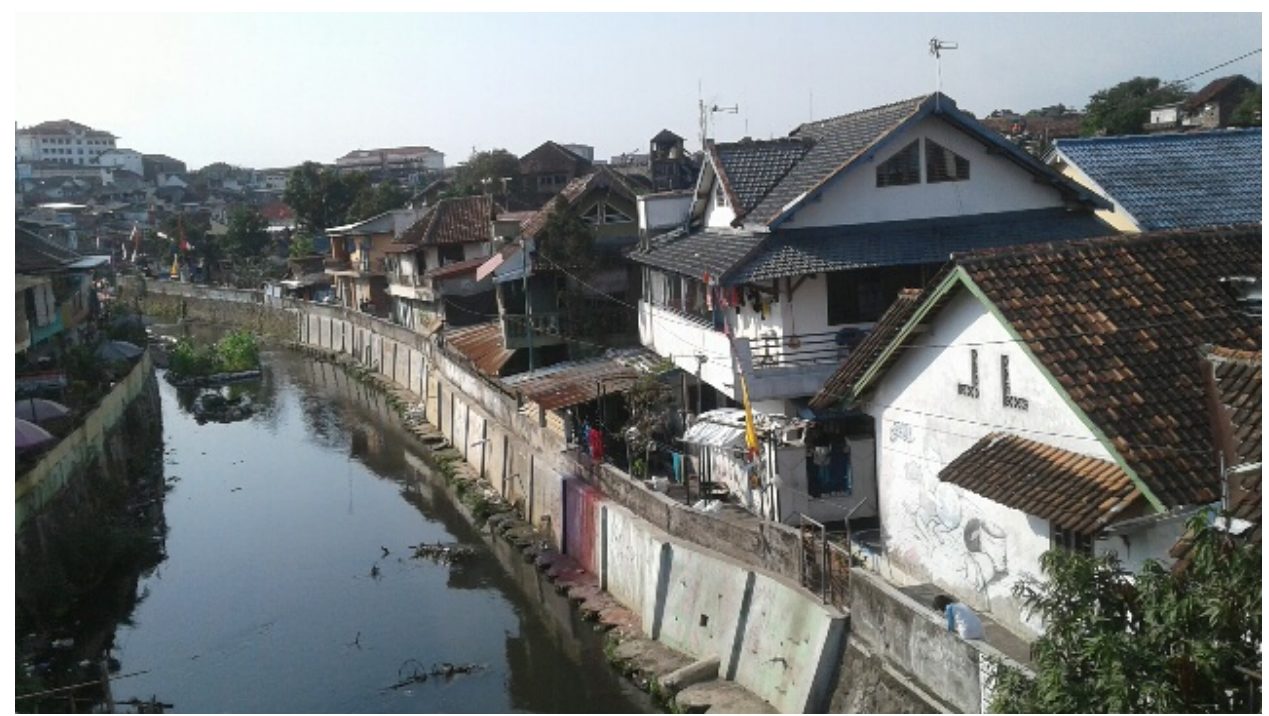

Photo1. Kampung Pulo and Ciliwung river. Author: own work.

Governor Purnama relocated half of the district's residents onto flats built and subsidised by the government, revitalised Kampung Pulo's remaining settlements and converted areas previously settled by squatters into parks with trees, sidewalks and adequate drainage systems.

Kampung Pulo is surrounded by diverse social components, including the urban elites, the commercial and industrial elites, the middle class, the low income but well-established households, the low-income renters and the lowincome migrants with no previous claim on the land or housing system (Ambrose, 1994). These urban elites include persons of wealth or political power who have been quick to recognise that urban land speculation and development is a historic opportunity to acquire immense wealth. These are people involved in urban development such as land-owners, land developers, development financiers, contractors/builders and marketers of final products.

Closely connected through politics, economic interests and/or marriage to the former elites, there are the owners and managers of major commercial and industrial enterprises (including MNCs), and they have two main substantial interests in land tenure issues and housing for the urban poor. Firstly, they must themselves fight for access to prime sites for their commercial and industrial activities, and secondly, they have a major concern that the cities in which they operate have large pools of workers willing to work for low wages and that they can displace the responsibility of providing housing for their workers to the government and the civil society at large, at the expense of the urban environment and the urban fringe areas. In Indonesia, this elite has not provided support for active and progressive land policies for the poor despite the government's clamouring them for support to provide housing for the poor in ways which will relieve industry of direct responsibility for housing its labour or from the pressure for higher wages (photo 2). The middle class is comprised of people who have struggled to achieve some measure of economic security that is often based on land and house ownership - frequently their largest single investment and anchor against possible future economic uncertainties. 


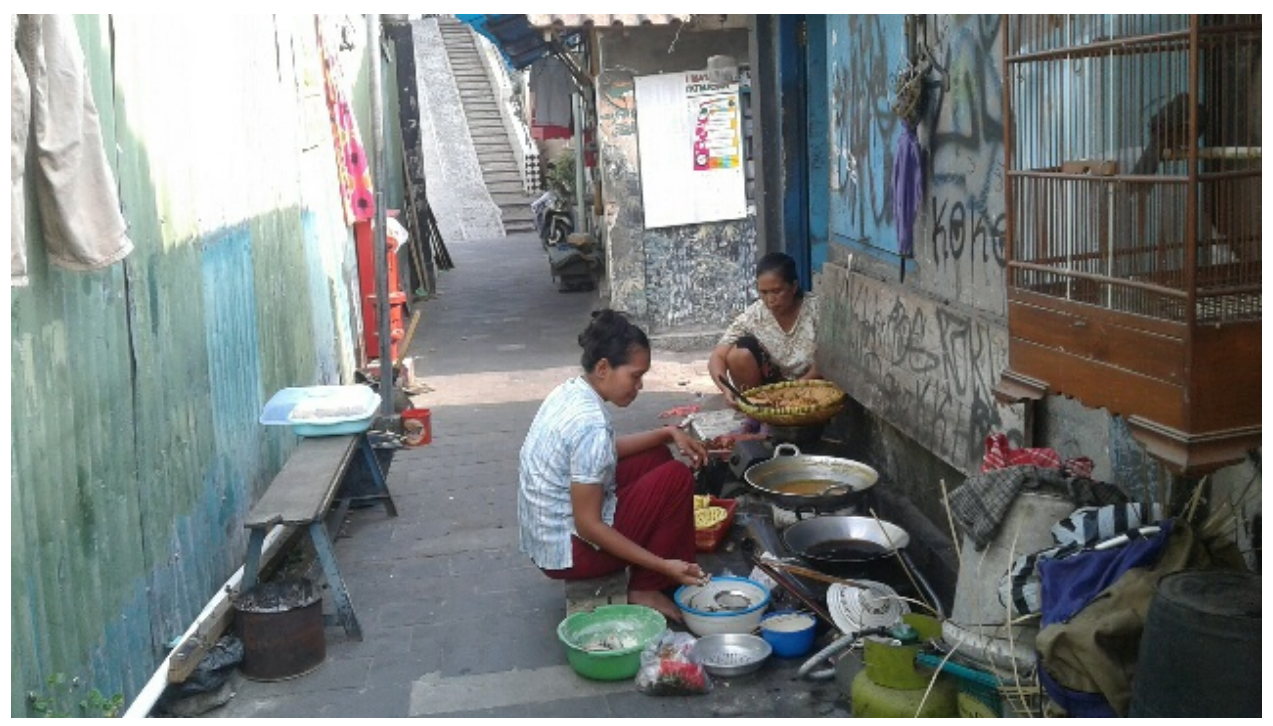

Photo 2. The life in Kampung Pulo.

Author: own work

They have known the insecurity of poverty and have strong feelings about losing the gains they have made. They frequently oppose new squatters and have climbed the slippery ladder to economic security, hence often opposing government effort to help the newly arrived poor in ways which would appear to impinge them.

One of the familiar characteristics of urbanisation in Indonesia, especially in Kampung Pulo, is the lower-income or working-class districts that are highly diverse and heterogeneous. Upwardly mobile families from this group may find that other investments, in their children's education or a business, could be more rewarding than investment in better housing. Moreover, land and housing programs which draw low-income households from their present settings may destroy delicate and complex but highly important support systems from the neighbourhoods which these households abandon. In Kampung Pulo, lowincome renters fall into two groups, namely strangers who rent on a market basis and paying relatives, whose economic contribution is tempered by obligations of blood or marriage. These people can be easily injured by wellintentioned but carelessly designed programs that fail to take them into account although they usually are not politically significant. The last category is the lowincome migrants with no previous claim to the land and housing system. This category is the most vulnerable to the unintended consequences of urban revitalisation and urban housing policies and programs. Ciliwung's urban revitalisation program focuses on local citizens and emphasises the need for an alternative development which highlights the roles of individuals, households and communities across various social components. These social components impart different forms of power capable of contingently restructuring the social and natural landscape.

Nonetheless, the case of Kampung Pulo also suggests that empowerment and development questions cannot be reduced to the micro-structures of household, community and locality. Issues of scale and complexity across regional and 
national levels require knowledge and understanding of the intricate social, political and spatial relations. Demarcation and seclusion will potentially lead to romantic ideals and inapprehensible sterility. To understand social relations within one locality requires an understanding of the historical events within other localities; likewise, facilitating responsiveness and inclusion within a particular dimension of the landscape requires events within other dimensions to function as catalysts.

Hence, devolution of authority and responsibility to the local level cannot function in isolation. In the case of Ciliwung, the very act of local management calls into question how the local will be defined in the light of governance and issues across space and jurisdictions. In the case of Ciliwung's urban revitalisation program, this reciprocal interplay of micro-practice and regional structure, each producing largely unintended consequences for the other, leads to the emergence of Ciliwung's explanatory 'model' for urban revita-lisation. This article discusses the devolution of authority and responsibility to local government and the community in surmounting local governance structure for securing land and housing for the poor and for revitalising low-income settlements. In the case of Ciliwung, community motivators, government agents and arbitrators from local NGOs all play a fundamental role in enabling local governance structure and promote the lateral relationships envisioned by the Indonesian government for devolution, participation and inclusive urban revitalisation. These community motivators are members and managers of selfhelp organisations which provide health care, education, religious services, and economic access/capital to the residents of Kampung Pulo and the low-income flats where some of the residents are relocated.

\section{Challenges and opportunities}

Urban revitalization programs along Ciliwung's river basin are not devoid of issues and challenges. Land use pattern in the Ciliwung river basin is shaped by three powerful overlapping forces, namely the creative and destructive forces of capitalism, the command and control, top-down and often violent measures used by the state in managing the population and the vernacular environment of the slums where the urban poor lives. First, the force of capitalism plays a crucial role in making Jakarta a city of power and influence and has a two-way relationship with the formal and informal land market.

Jakarta's capitalist modernisation rides on the back of informality: the urban elites and owners of major commercial and industrial enterprises land in strategic urban and peri-urban areas through social connections, political influence, economic power, market speculations, legal manipulations and tempering in policy and regulatory decision-making processes. Nonetheless, commercial and industrial elites also rely on cheap labour acquired through their absence of involvements in providing housing for workers. Hence, the costs of housing Jakarta's workforce is externalized to the much cheaper informal land and housing market. Second, the state, a powerful agent, plays a role in classifying civil society and naturalising differences. The state denotes the urban underclass as the floating mass - the disorganised, unruly and often brutal 
group of people - which the state targets from time to time through acts of violence. These acts of violence include forced eviction from slum areas, forced relocations onto flats and low-income apartments, the deliberate demolition of squatters' homes and the seizure of their possessions. These were the initial actions taken by Jakarta's government when relocating squatters from their slum environment along Ciliwung's riverbank into housing flats. Major conflicts between squatters and government officials ruptured many times, and the Indonesian army came and instilled order while securing the clearance of the riverbank throughout six months after which squatters complied and moved their belongings to the newly built low-income flats built by Purnama's government. During the initial phase of settlement, many issues prevailed, including arbitrary solid waste disposal, vandalism, refusal to pay building maintenance fees, residents' clamouring for compensations for being relocated to housing flats (e.g. ganti rugi) and residents' demanding permits to return to the river basin to rebuild their homes (Bourne and Simmons, 1978).

Nonetheless, with ad hoc and regular assistance, support and counselling by government agents, NGO personnel, community motivators, social workers and religious and health professionals, residents of the low-income housing flats gradually adjusted and adapted to their environment and tried to make up for income lost due to the relocation by opening food stalls and small shops (e.g. warungs \& toko kelontong) in designated places around the flats that have been installed by the provincial government and the Department of Public Works. The masses in the slums constitute the third contesting force. They have their own networks to survive socially, economically and create a space for themselves within the power structures of the state and capitalist domination. In the case of Kampung Pulo, they have creative impulses and take pride in making their own space, vying their own land and building their own housing through loans given by family members, inheritance and other social and economic means. The urban poor is almost always envisioned as powerless, disorganised and incapable of empowering themselves. Rather than being a homogeneous mass of helpless individuals, Kampung Pulo's poor often form strong communities led by neighbourhood leaders who play an active role as in the making and managing of their city.

A grave issue relating to flats and low-income apartment facilities is that they are built on limited government land which is not readily available and requires contentious land acquisition processes which are often exacerbated by conflicting and overlapping legal claims to the land. Moreover, low-income apartment facilities in Jakarta are built and funded entirely by the government and are heavily subsidised in maintenance and service fees. In many cases, fees for access to water and electrical services in low-income flats are also heavily subsidised by the government (Press, 1980). These issues may impede their sustainability. Nonetheless, evidence from Kampung Pulo suggested that residents living in flats and low-income apartments gradually act in a way that benefits the overall good even when they are avowing individual rights. The case of Ciliwung's revitalisation program suggests that different circumstances create different responses. Collective needs in Kampung Pulo are translated differently by the various resource users. The urgency of voluntary cooperation to protect the urban environment and low-income housing facilities is contingent upon 
individual constructions, competing for timelines and complex social landscapes. Community groups are social agents who influence and are influenced by their surrounding community of social practice. Customs and sentiments also play a role in shaping group dynamics, thus opening the possibility for collective action and social cohesion within contrasts and struggles in urban revitalisation and urban housing for the poor.

\section{The political framework}

In Jakarta, and especially in the case of Kampung Pulo, control over land and housing for the poor is a political issue, and the pursuit of legal tenure requires a deep understanding of dynamic political conditions and available strategic options. The demand for land tenure for the poor is difficult to pursue in practice. The pursuit of land tenure for Jakarta's poor is not restricted to a particular ideology: politicians of all persuasions pursue it if it appears to be in their interest to do so. When political conditions are right, land tenure and its legalisation can be introduced. When political conditions are not favourable, as in cases where land-owning groups demand capital-intensive construction wield considerable influence and the ruling elite cannot afford to alienate them in exchange for the support of the urban masses, land tenure legislation is not likely to be introduced. By advocating land tenure security for the poor, political elites strike in favour of the masses.

This was done by Governor Purnama's successor (Anies Baswedan) at the beginning of his administration to win support from Jakarta's poor in Kampung Pulo, but failed to take off and endure due to the lack of sustained political will from Baswedan's government and other groups, including Kampung Pulo's residents who preferred the casual nature of informal and illegal settlements and investor groups who lobbied the government to secure their access to land, its legislation, its legal framework and its permit and taxation system. Jakarta's politicians are well aware that siding with the masses has severe political liabilities. It invites oppositions from the landlords and urban and commercial/industrial elites. Mr Purnama's successor is not only aware of this, but also aware that land tenure program encourages the masses to go beyond land issues and into more broad-based social issues which the ruling elite may not be able to handle.

Changes within Jakarta's political regime and governance administrations led to uncertainties and ambiguities for continuing Ciliwung's urban revitalisation pro-grams which were initiated during Basuki Tjahaja Purnama's government administration. Moreover, Jakarta, a city and also the nation's capital, is heavily influenced by the politics of the nation and vice versa. Kampung Pulo's poor became a political commodity and a political consumer whose votes, economic alliance and political assonance were crucial for regional and national politicians vying for local and state power. In his campaigns, Mr Purnama's successor (Anies Baswedan) gained votes from Ciliwung's poor by protecting them and allowing them to stay in their slum environment and not forcing them to relocate to housing flats. In his campaigns and initial government administration period in late 2017, Anies Baswedan promised Kampung Pulo's poor a safehaven along the Ciliwung river bank and mandated that Ciliwung's urban 
revitalisation and relocation program be put on hold legally, financially and administratively when his administration began in late 2017. During Basuki Tjahaja Purnama's administration, it was Governor Purnama's stern leadership, brazen character and un-wielding determination which enabled him to forge alliance with the media, the army and the various ministries and provincial government departments to downplay the influence of political elites and the business community and to relocate squatters and revitalize the riverbank environment settled by remaining residents.

Governor Purnama did not succeed in passing a legislation to secure land and housing for the poor and to safeguard the revitalisation of Kampung Pulo; but he succeeded in enforcing a sound principle of territorial distributive justice among officials, politicians and the business community through the provincial government's elevated status and its cross-cutting decision making authority across horizontal and vertical governance jurisdictions. As well, evidence from Kampung Pulo suggested that success in mobilising and engaging community user groups stemmed from the ability to build a sense of ownership, belonging, and pride among community members towards their joint effort. This joint effort, when aligned with one's identity and imagination, led to the emergence of stewardship and the need to give back to the social and physical environment for their protection.

The case of Ciliwung suggests that social agents are shaped by, and help shape the context in which they act. Moreover, participation and engagement are not dictated and static but emergent and dynamic. The case of Ciliwung's urban revitalisation and relocation program suggested that if community groups are operating in a system that rewards individuals for power expansion, bureaucratic advancement and capitalist growth, groups and individuals will respond to this stimulus. If community groups are in an environment where reciprocity, civic duty and a shared purpose to protect the social and physical environment are present, the social and cultural institutions which emanate at the community level will reinforce the above values. The case of Ciliwung also suggests that the roles which command and obedience play in shaping order, coherence and a collaborative framework should not be undermined.

\section{Land tenure and housing for the poor}

Indonesia has long been known for its dynamic informal housing sector, by the self-provisioning of housing by owners through incremental processes, where the house is built over time, sometimes over decades. In almost all Indonesian cities, more than half of the houses acquired between 2002 and 2007 were selfbuilt, and a large share was acquired through other means, such as inheritance or gifts. Only a small portion of the new housing was purchased from a developer or builder. In the case of Jakarta's Ciliwung river basin, squatters find themselves at a relative location advantage, being close and visible to the sources of power and authority. Their concentration in Jakarta's metropolitan centre enabled them to enter the competition arena for the allocation of national resources, be it land, services, funding, or other privileges (Potter and LloydEvand, 1998). Jakarta's provincial government was well aware of the danger of an uncontrolled and frustrated squatter population resorting to demands, 
resistance and violence. Subsequent to Governor Purnama's administration, this threat to the government's authority and stability to rule forced Baswedan's government to subdue attempts for organising the squatters and working with squatters to solely further its own political goals.

As well, the Dutch administration did not extend its land registration system across the entire country but limited it to areas where it had economic interests. This allowed for additional or customary indigenous system of land ownership to survive in areas where land was not registered to individuals. It also allowed indigenous inhabitants to grab land and squat in places that are physically strategic, fertile and economically viable. Law no 5/1990 on Basic Agrarian Principles recognizes a customary right (hak adat) to land, together with a freehold right (hak milik), a cultivation right (hak guna usaha or HGU), a right to construct or use buildings (hak guna bangunan, HGB) and a usage right (hak pakai). However, the regulations governing the transfer and legalisation of indigenous land and vacant land used by squatters remain unclear until now.

The Basic Agrarian Law or BAL did not overcome the administrative dualism between land that had been registered under the provisions of the Basic Agrarian Law and land that was subject to customary and/or informal regulations. In addition, the provincial government is claiming ownership rights of the land in Kampung Pulo since officials perceive the vicinity as a catchment and drainage area worthy of protection from the government to safeguard the city against flooding (Ayu Puspito Sari, 2018). Moreover, the legalisation of land in Jakarta is almost always a cumbersome process involving individual plot boundary surveys which must be correlated with the approved physical layouts, calculation of charges payable by residents and the verification of documents by the proper authorities. As well, the above process can begin only after an adequate response from residents and the deposit of the required charges. This led to the deterrence of land registration and legalisation among groups across social stratifications, especially among the country's urban poor.

House ownership statistics in Indonesia refer mainly to building tenure and not to land tenure. Houses built on land rented or leased or governmentcontrolled land is very common for Jakarta's poor. Moreover, Indonesia's rapid urban growth has increased the number of low and middle-income residents in cities and suburbs, but the availability of land and housing for the urban poor has not kept up with demand. According to data released by the National Development Planning Agency, the backlog reached 12 million units in 2013 and is continuing to increase. Most houses built over the past decade have been built by owner-occupiers (rather than government or private developers), but many of them were substandard. In 2012, four million Indonesians lived in very poor quality dwellings, some of which were not permanent structures, and another 13 mil-lion were homeless. While the number of houses constructed by developers each year has increased, many remain unsold due to high asking prices. For the most part, Jakarta's poor who are also owner-occupiers acquired their houses through informal, incremental processes, after squatting on the land or using inheritances or loans from a family member to purchase land use rights and build their homes. These arrangements have become a quick and ready solution to address the housing backlog. However, informal processes are inefficient in providing low and middle-income residents with adequate access 
to urban ame-nities and infrastructure such as water, sewage, electricity, roads or even the public transport system. Meanwhile, economic growth has been pushing up land prices, squeezing low and middle-income Jakartans out of the housing market. Unable to access well-located land, Jakarta's poor are forced to squat in locations that may be hazardous, without proper services and amenities, or located far from the city center, without any assistance in terms of planning or provision of basic services, or even official recognition of their existence.

Securing land for the government to build housing flats on is also quite challenging. Jakarta's provincial government has legally owned the land for the housing flats which house former Kampung Pulo squatters, as it obtained it after clearing it from run-down office spaces no longer in use. Jakarta's provincial government had trouble securing land over which it had no legal entitlement. The dominant role of the centralised National Land Agency (Badan Pertanahan Nasional) in determining land use and allocation, in granting land use permits and in monitoring and controlling land legalisation processes deterred the administrative processes for land acquisition and land legalisation by Jakarta's provincial government to the detriment of lower-income people (Kaiser, Godschalk, Chapin and Chapin, 1995). Moreover, land acquisition and land tenure security by the provincial government for the poor were also deterred due to unclear property rights, inefficient bureaucratic procedures, high transaction costs and poor implementation and enforcement.

Consequently, low and middle-income Jakartans face numerous obstacles in accessing housing with secure land rights. At the same time, this situation creates incentives for the construction of informal settlements, reduces the incentives for private developers to build houses for lower-income people and deters the poor's access to urban infrastructure and amenities. The difficulty with Ciliwung's revitalisation and urban poor housing program is that it requires involvement in the commercial sector which was largely curtailed during Governor Purnama's administration. While Jakarta's private developers are enthusiastic and knowledgeable when it comes to commercial operations, they are not keen to become involved in low-income housing. Jakarta's government, on the other hand, as well as non-profit voluntary organisations, can effectively work on low-income housing but is not particularly experienced in market operations. The government is less efficient and can waste all or most of the potential profits required for cross-subsidies by their inefficient management of construction and sale of properties. It accounted for why most government-built low-income flats in Jakarta were eventually renovated and managed by private developers who lease the property to those outside the low and lower-middleincome groups. Government officials stated that flats within Ciliwung's vicinity are restricted for Kampung Pulo's residents who were evicted from the riverbanks or who preferred to live in low-income flats.

\section{The institutional framework}

The market economy in Jakarta is rapidly transforming the land into a commodity which can be freely bought and sold. Transactions in the urban land market increasingly reflect economic relationships between persons and groups rather than social relationships. Participation in the land market is mostly 
restricted to those sectors of the economy with strong capital and people and groups that can obtain access to financing capital. It is largely barred from people with low earnings and small savings who cannot obtain access to such capital. Nonetheless, in Jakarta, the urban land market does not fully operate as a free market. It is subject to varying degrees of control over land use, to regulations governing land transfer, to restrictions on development, to compulsory acquisition and taxation.

However, government control is also subject to political pressures by different groups with interests in using land and benefiting from land transactions. In the case of Ciliwung, as political power shifted to the new governor Anies Baswedan, significant changes in the structure and operation of land markets occurred in favour of the business and political elites. The provincial government during Purnama's administration initiated a non-capitalist definition of efficiency in urban land governance while encouraging redistributive justice, community welfare and ecological restoration. Governor Purnama considered the limits of economic commensurability and integrated them into policymaking at the sub-national level, fostering the protection of ecosystem services and the communities which gravely depend on them. The government during 's administration needs "to take seriously about degrowth, localisation, postcapitalism and the imperative of collectively changing the rules of the game" (Hornborg, 2017). There is, however, a consensus among government officials that the housing conditions of Jakarta's poor are unsatisfactory and that past action to ameliorate them is highly ineffective without comprehensive transformations which involves legal, political, economic, bureaucratic and social and land reforms (Linn, 1983).

In the case of Kampung Pulo, the provincial government's principal partner responsible for directing and managing construction, relocation and revitalization, namely the province's Department of Public Works, devoted a majority of its time, manpower and funding on the construction of flats and infrastructure in revitalized areas in the most effective and timely efficient manner. The province's Department of Public Works lacked coordinating power with the national ministries and other government departments at the provincial level. Moreover, the institution also lacked authority and decision making power for land tenure acquisition (which is within the jurisdiction of the National Land Agency and the Provincial Planning and Development Board), lacked financial and budgeting control over the provincial and national budgets, and lacked power and authority to enforce other government departments capable of providing the community with health and human services.

Hence, the province's Department of Public Works was not endowed with sufficient power and authority for coordination, linkage and asserting mandates across the horizontal and vertical government departments. In such a case, a more sustained, in-depth and enforcing role from the provincial government, especially from the governor's office, was necessary and taken during Purnama's administration to ensure swift coordination, consistent mobilisation and cohesive implementation. To relocate residents and revitalize Kampung Pulo, during Governor Purnama's administration, the government maintained considerable command and control type regulation of society, but also became more extensively involved in meta-governance, in steering society by setting the rules of the 
game, distributing resources, requiring others to take responsibility and selfregulate, and by establishing the narratives that shape the nature of problems to be solved and the policy instruments appropriate for resolving them.

One of Governor Purnama's most remarkable achievements was setting up the institutional arrangements to facilitate housing and a safer environment for the poor. Governor Purnama maintained a considerable command and control type regulation of society by enforcing firm and consistent policies to conserve ecologically sensitive riverbank areas, to evict opposing squatters by force when necessary, to mandate the installation of adequate drainage, canals, wastewater treatment facilities and solid waste disposal sites in Kampung Pulo and to discipline and regulate the flow of traffic surrounding the vicinity. Governor Purnama's administration also became more extensively involved in metagovernance, in steering society by setting the rules of the game, distributing resources, requiring others to take responsibility and self-regulate.

The government allowed this by creating community self-help groups mentored by NGOs and pairing them with extension agents from government departments to assist in providing services for community groups living in flats and in the revitalised riverbank vicinity. These include health and human services (e.g. education for the young, family planning for couples, nursing for the elderlies, religious services, nurses on-call, community clinic, counseling, subsidized medicine), environmental services (e.g. collective solid waste disposal and recycling, collective wastewater treatment, maintenance of drainage, canals, roads, parks, lightings and other public facilities in the vicinity), business startup services (e.g. access to low interest loans, capital, facilities, business coaching and mentoring, marketing assistance), and security services (e.g. community based security services or Pos Kamling, daily policing by professional security officers to avoid possible vandalism, formation of conflict-resolution groups for residents in contention and delinquents).

Research findings suggest that participation for protecting common resources requires the creation of a new social and political space which gives a sense of importance and identity to community user groups. At the heart of this is the need to engage community groups through pride, identity and imagination. Active engagement of this nature can lead to reflection and change, stimulating groups and individuals to be more responsive in assuming responsibility for protecting the social and physical landscape. Through the influence of the media, the country's armed forces and Indonesia's leading political figures, Governor Purnama legitimized and enforced the narratives which shaped the nature of problems to be resolved (e.g. regular flooding, destruction of the riverbank ecosystem and illegal settlements) and the policy instruments appropriate for resolving them (e.g. provincial government orders and regulations, subsidized housing programs for the poor, cross-subsidies between government departments, mandatory taxation and CSR for the business community and anti-corruption measures within the government sector at the provincial level). Actions taken by Governor Purnama during his administration generated more than enough liquid cash to build housing, roads, infrastructure and facilities for the public in general and the poor in particular.

The case of Ciliwung suggests that although participative engagement needs to come from local contexts to enable social capability and environmental 
responsiveness, the roles which command and obedience play in shaping order, coherence and a collaborative framework for urban environmental governance cannot be undermined. Another issue which beset flats and low-income apartments is the lack of motivation from residents to pay for amenities and services accrued (e.g. electricity, gas, building and infrastructure maintenance, solid waste disposal services). The roles of community motivators, government officials, counsellors and NGO personnel in working alongside residents and community members extend beyond comforting them in their new surroundings to empowering them to manage housing and public facilities in the long run independently. The enduring management of Ciliwung's flats requires advocacy and communicative planning alongside top-down rational planning based on legal directives, policy interventions and practical imperatives.

\section{Best practices from Kampung Pulo: resolving market rationality and urban dualism}

Experience from Ciliwung suggests that the implications that market rationality and market competition had on groups and individuals were contingent upon complex social and political practices within the locality. The provincial government during Purnama's administration initiated a non-capitalist definition of efficiency in urban land governance while encouraging social justice and community welfare (Deininger, 2003). Governor Purnama considered the limits of economic co-mmensurability and integrated them into policy-making at the sub-national level, fostering the protection of Ciliwung's ecosystem services and the communities which gravely depend on them. He also focused on "the imperative of collectively changing the rules of the game" (Hornborg, 2017) when he incorporated harsh transparency and accountability measures in Jakarta's provincial budget planning and implementation, mandated land reform to reduce available land for commercial areas and luxury apartments and ordered that vital areas within the Jakarta municipality be restored in its ecological functions and/or left vacant for the construction of roads, parks, sidewalks, storm drainage, wastewater discharge facilities, public transport infrastructure, bus shelter and open public spaces.

He also instilled stringent anti-corruption measures in the development and construction of urban infrastructure, forced the relocation of squatters and street vendors to safer, newly constructed areas with adequate facilities and imposed substantial taxes on the business community. Governor Purnama was very much aware that the government often introduced discriminatory systems of property rights to stimulate economic growth to the detriment of the poor and public majority and these systems often reduced efficiency, undermined equity and had to be maintained by force (Hoch, 1994). It is because of this that land reform was conducted and perceived necessary by Governor Purnama to correct the bias introduced by non-market interventions.

Decentralisation and devolution in urban revitalisation have to take into account different forms of perception underlying community involvement and how these encourage groups and individuals to evolve behaviour which commensurate their responsibilities. Facilitating participation for protecting common resources requires a new social space which provides a sense of importance and identity to community user groups in Ciliwung. 
The need to engage community groups through identity and imagination is at the heart of this process. Hence, their sense of importance, recognition and obligation to act for the collective good will motivate them to perform extraordinary actions. Research findings also suggest planned changes within policy measures are most likely to result in highly restrictive environments, whereas social, psychological and political engagements are most likely to result in a new space for empowerment and incorporation. Dualism is the existence of two dichotomous characteristics, attitudes and behaviour and is usually transitioning from one to the other. Examples of dualism include the differences between the urban and the rural, the old and the new, the natural and the artificial, the precapitalism and the capitalism and the informal and formal. A dualistic city is a city in which the population have a double culture and a city which is influenced by or is struggling to overcome the adverse effects of the dualistic culture (Devas, 1993). Jakarta is a dualistic city with its clear demarcation between the rich and the poor, the commercial areas and the shanty towns and the formal residential areas and the informal makeshift community of the urban squatters. Jakarta's dualistic nature becomes a severe obstacle for urban revitalisation, integration of marginalised communities and sustainable governance (Hizbaron and Hasanati, 2016). Hence, there is the need to build linkages and to integrate and harmonise the various segments of society within the city to instil reciprocity as well as social and economic capital. In Jakarta, the roles and contributions of many town centers within commercial and residential areas are decreasing and are contributing to the weakening of the integrated urban systems.

To integrate Kampung Pulo's housing flats and revitalised areas into Jakarta's middle class and the city's commercial and residential areas, Governor Purnama built town centers within Kampung Pulo (Perera, 2006). They included facilities such as parks, sidewalks, meeting hubs, transport vehicles and stalls for residents to sell street food and merchandise and to allow them to mingle. The reformation of Kampung Pulo's town centers to be walkable and pedestrian friendly was a very important step for people to meet each other (Rondinelli, 1983). Moreover, during this time, many town centers of the various segments of society and the city were also revived, reformed and reconnected as the place of networking of the local people, namely, as the center of networking of the civic sector as well as the business sector (e.g. place of gathering, meeting, exchanging, discussing, dealing).

Physical reformation and linkage of town centers, in the case of Kampung Pulo, contributed to the strengthening of local people's networking capacity and the enduring integration of newly revitalised areas (Shubert, 1996). In addition, slum residents, including those living in Kampung Pulo, often display behaviour commonly referred to as 'slum culture' marked by deviant behaviour, by apathy towards government authority, the middle class and the outside communities, and by social isolation. In addition to the creation of town centers, access to integrated facilities found within the locality such as access to health care services, family planning services, religious services, educational services, administrative services, counseling services, youth and women's empowerment programs, local cooperatives and business start-up programs assisted in empowering and linking these marginalised communities to the outside world (Hardjowigeno and Widiatmaka, 2007) . 


\section{Conclusions}

Residents of Indonesia's slum areas, including that of Kampung Pulo's, are a marginalised community, lacking access to the nation's social, economic and political resources. They are socially rejected, culturally undermined, economically exploited and politically suppressed by the dominant majority of the country's population. They are at the bottom of the country's social ladder. An initial step for empowering, protecting and integrating them, requires the social and political structure of today's Indonesia to acknowledge and respect their presence, roles and participation in shaping the country's landscape (Harvey, 1973). There is the need to formally acknowledge and protect their identity, place and roles in the country's social and political functionalities. This can be done by giving them official identity cards (e.g. kartu tanda penduduk) which stipulates their residency in Jakarta, by endowing them formal land and housing permits to reside in Kampung Pulo and by enlisting the occupations and services they perform (Morphet, 2011).

They contribute to the country's economy by shaping the informal sector; contribute to the country's social make-up by shaping the dynamic labour force and the cohesive class relations across groups and ethnicities; contribute to the country's political stability by conveying their votes and legitimizing current government and political administrations; and contribute to the country's cultural tolerance by shaping subcultures which corroborate the mainstream Indo-Javanese culture (Khudori, 2002). Their ac-tive citizenship and participation in the region's day to day life cannot be undermined, and their uprisings can mean reverberated political instabilities across cities and regions.

Economic empowerment of Kampung Pulo's residents requires residents' access to information, jobs, financial resources, loan and credit schemes, vocational training and programs for the creation of small and medium enterprises. Political empowerment of Kampung Pulo's residents re-quires their protection, acknowledgement, place, status and reverence in the country's social hierarchy, voting rights and access to ethnic solidarity groups, political parties, the media and the People's Representative Council. Social and cultural empowerment of Kampung Pulo's residents requires their access to health and human services, land and housing tenure and urban infrastructure facilities.

Research findings suggest the importance of the following in securing land and housing for the poor and revitalizing the Ciliwung river bank: (i) partnering with the formal and informal sectors to attain land and housing security, (ii) instilling consistency in land and housing development plans and permits, (iii) creating a more integrated city through networking, integrated facilities and the development of pedestrian-friendly town centers, (iv) instilling collaborative governance and advocacy planning to motivate and empower citizens, and (v) building collective action for protecting the revitalized urban environment and low income housing flats through identity, imagination and sense of ownership.

\section{References}

Ambrose, P. (1994), Urban Process and Power, Routledge Publications, London. 
Ansari, J. and von Einsiedel, N. (1998), Urban Land Management: Improving Policies and Practices in Developing Countries of Asia, Mohon Primlani Press, New Delhi.

Benveniste, G. (1991), Mastering the Politics of Planning, Oxford University Press, San Francisco.

Bourne, L.S. and Simmons, J.W. (1978), Systems of Cities: Readings on Structure, Growth and Policy, Oxford University Press, New York.

Chiddick, D. and Millington, A. (1984), Land Management: New Directions, Cambridge University Press, London.

Deininger, K. (2003), Land Policies for Growth and Poverty Reduction: A World Bank Policy Research Report, Oxford University Press, Washington DC.

Devas, N. (ed.) (1993), Managing Fast Growing Cities: New Approaches to Urban Planning and Management in the Developing World, Longman Singapore Publishers, Singapore.

Harvey, D. (1973), Social Justice and the City, John Hopkins University Press, Baltimore.

Hardjowigeno, S. and Widiatmaka (2007), Evaluasi Kesesuaian Lahan E Perencanaan Tataguna Lahan, Gadjah Mada University Press, Yogyakarta.

Hoch, C. (1994), What Planners Do: Power, Politics E Persuasion, American Planners Association Press, Chicago.

Hornborg, A. (2017), "How to turn an ocean liner: a proposal for voluntary degrowth by redesigning money for sustainability, justice, and resilience", Journal of Political Ecology, vol. 24, p. 623-632.

Hizbaron, D.R. and Hasanati, S. (2016), Menuju Kota Tangguh di Sungai Code, Yogyakarta: Perencanaan Integratif Perkotaan dengan Pendekatan Pengelolaan DAS dan Pengurangan Risiko Bencana, Gadjah Mada University Press, Yogyakarta.

Kaiser, E.J, Godschalk, D.R, Chapin, F.S. and Chapin, F.S.Jr. (1995), Urban Land Use Planning, University of Illinois Press, Chicago.

Khudori, D. (2002), Menuju Kampung Pemerdekaan: Membangun Masyarakat sipil dari Akar-akarnya Belajar dari Romo Mangun di Pinggir Kali Code, Yayasan Pondok Rakyat, Yogyakarta.

Linn, J. (1983), Cities in the Developing World: Policies for Their Equitable and Efficient Growth, Oxford University Press, Washington D.C..

Morphet, J. (2011), Effective Practice in Spatial Planning, Routledge, London.

Potter, R.B. and Lloyd-Evand, S. (1998), The City in the Developing World, Longman, Singapore.

Press, I. (1980), Urban Place and Process: Readings in the Anthropology of Cities, Mac Millan Press, New York.

Rondinelli, D. (1983), Secondary Cities in Developing Countries, Sage, London.

Shubert, C. (1996), Building Partnerships for Urban Poverty Alleviation, UNCHR, Washington D.C..

Perera, R. (2006), Prospects of Multi-Habitation Approach for Poverty Reduction in Asian Cities, AIT Press, Bangkok.

URDI, (2005), Pembangunan Kota Indonesia dalam Abad 21: Konsep dan Pendekatan Pembangunan Perkotaan di Indonesia, Yayasan Sugijanto Soegojoko, Jakarta. 